UDC 338.43:658

http://doi.org/10.21272/mmi.2019.2-13

JEL Classification: M10, M11, M19

Jolita Greblikaite,

Ph.D., Vytautas Magnus University, Lithuania

Audrone Ispiryan,

Vytautas Magnus University, Lithuania

Deimena Montvydaite,

Vytautas Magnus University, Lithuania

\title{
DEVELOPMENT OF BERRY FARMS IN EUROPE: ORGANISATIONAL AND MANAGEMENT ISSUES
}

\begin{abstract}
This paper summarizes the arguments and counterarguments within the scientific discussion on the development of berry farms in Europe. The main purpose of the research is to reveal the possibilities and ways of development of berry farms in Europe, focusing on organisational and management issues. The research object is berry farms and farming. The main tasks of the research are: - to analyse the situation of berry farming in EU and other Europe countries; - to provide the possibilities of development of berry farms at international level (high added value products, high added value business, etc.); - to emphasize key points of further berry farm's development in Europe. The research covers the actual agriculture management sphere as berry farming. The article provides an analysis of berry farms and farming in Europe with a detailed statistical comparison. There is studied the main kind of berries, that are grown in Europe: strawberries, raspberries, gooseberries, currants, blueberries, cranberries and berries nes that includes blackberry, loganberry, white, red mulberry, myrtle berry, hackberry, and dangleberry. Statistical data of the area harvested, yield and berry production is analysed. Organisational and management issues are presented and analysed. The main actual spheres of potential competitiveness and development of berry farms are discussed. Statistical data analysis revealed the main berry growers and the amounts of the main different kinds of berry production in Europe. After the literature review and the analysis of the successful berry growers' berry farming management examples, the main organisational and management features of successfully berry farm's development were disclosed. The results of the research can be useful for developing successfully berry farming in European countries. The construct of the research is based on situational analysis of berry farming in the European countries based on statistical comparative analysis combined with in-depth analysis of scientific literature. Data are presented from different statistical sources. Analysed period of data is the year 2013-2017.
\end{abstract}

Keywords: berry farms, berries yield, berry farming, berry production, management in agriculture.

Introduction. In Europe berry farms are growing different kinds of berries: black currant, aronia, sea buckthorn, raspberry, strawberries etc. Similar kinds of berries are grown in neighbourhood countries: Lithuania, Poland, Ukraine, Russia, Scandinavian countries, Other EU countries specialised in some kinds of berries: Spain in strawberries, Serbia in raspberry, Sweden, Finland - cranberry, cowberry. Countries which are situated in the northern areas are growing less berries more adjusted to warm climate conditions. On the other hand, Ukraine or Russia could produce berries cheaper because of not so strict growing rules, for example, related to fertilisation. Strawberry farms from the ES countries can provide in the market production with lower prices. Lithuanian berry farm suffers quite severe competition in berry market because of market and climate conditions, higher costs and etc. Farmers are trying to stay competitive in the market and seeking for solutions how to maintain it. The importance of berry farming is based on numerous scientific studies. Authors highlight berries' economic importance (Macori et al., 2018; Skrovankova et al., 2015). Scientific researches have showed that berry market is expected to expand (Invenire Market Intelligence, 2018; Tefera et al., 2018; Willer et al., 2015; Barro, 2014). As it was established in many researches, in the past decades berries have gained more consumers' attention as they look out for healthier dietary options (Falco et al., 2019; Invenire Market Intelligence, 2018; Lefevrea et al., 2018; Tefera et al., 2018; Vittori et al., 2018; Lozano et al., 2016; Bhat

Cite as: Greblikaite, J., Ispiryan, A., \& Montvydaite, D. (2019). Development of Berry Farms in Europe: Organisational and Management Issues. Marketing and Management of Innovations, 2, 141-159. http://doi.org/10.21272/mmi.2019.2-13 

Issues

et al., 2015). Scientists analyse berries' nutritional composition and their substances that are useful for human health (Baby et al., 2018; Lefevrea et al., 2018; Castro et al., 2015; Skrovankova et al., 2015; Juranic et al., 2005; Kowalenko, 2005). Even though researchers highlight the importance to meet the consumers' demand of beery production (Bhat et al., 2015; Farrugia et al., 2015; Invenire Market Intelligence, 2018), there are just a few studies about successful berry farming development (Invenire Market Intelligence, 2018; Zbanca et al., 2018; Perea et al., 2017; Matyaszek et al., 2012). Some authors analyse berry breeding (Vittori et al., 2018; Feliziani et al., 2016), some concentrate into berry cultivation (Tefera et al., 2018; Bhat et al., 2015; Matyaszek et al., 2012), berry harvesting (Maunula et al., 2013) or berry production (Guerrino et al., 2018; Bhat et al., 2015; Nile et al., 2014; Velioglu et al., 2002). However, there is still a lack of researches investigating berry farming management aspects, that would help berry growers to successfully develop their berry business. Therefore, it is important to analyse berry farming situation in Europe, including statistical data analysis, in order to identify the biggest berry producers and to investigate their berry farming aspects as an example of successfully berry farming management as a foundation for berry business development.

Literature Review. Berries, such as raspberries, blueberries, blackberries, redcurrant, and lingonberries, represent an important type of fresh produce in Europe, in terms of production volume and economic (Macori et al., 2018). Berries, especially members of several families, such as Rosaceae (strawberry, raspberry, blackberry), and Ericaceae (blueberry, cranberry), belong to the best dietary sources of bioactive compounds. They have delicious taste and flavour, have economic importance, and because of the antioxidant properties of bioactive compounds, they are of great interest also for nutritionists and food technologists due to the opportunity to use bioactive compounds as functional foods ingredients (Skrovankova et al., 2015). Some of the most commonly cultivated and consumed berries include strawberry, raspberry, blueberry, blackberry, and Indian gooseberry (Baby et al., 2017). These berries are highly recommended because the effects of their antioxidant compounds on human health have been explored by various in vitro and in vivo studies (Juranic et al., 2005; Skrovankova et al., 2015). Berries, in general, are rich in sugars (glucose, fructose), but low in calories. They contain only small amounts of fat, but a high content of dietary fibber (cellulose, hemicellulose, pectin); organic acids, such as citric acid, malic acid, tartaric, oxalic and fumaric acid; certain minerals in trace amounts (Kowalenko, 2005); some vitamins (ascorbic acid and folic acid); and phytochemicals, such as phenolic compounds. These compounds could be a good option for the food industry to use as functional foods ingredients (Skrowanka et al., 2015). However, the chemical composition and the content of each individual component of represented berries as well as the quality of the fruits is highly variable depending on the cultivar and variety, growing location and environmental conditions, plant nutrition, ripeness stage, and time of harvest, as well as subsequent storage conditions (Skrowanka et al., 2015). Those are the reasons why farmers in different countries are specialising in growing different kind of berries. In order to establish the possibilities of berry farm's development in Lithuania, the broader analysis of berry farming in Europe is performed. According to Littori et al. (2018), the most common berries worldwide are cranberry, blackberry, blueberry, raspberry and strawberry, with elderberries, mulberries and other less common red fruits being specific of some particular environments. International Food and Agriculture organization of United Nations (2019) collects official data related to berry cultivation and production. There are provided harvested area, yield and production quantity statistics of strawberries, raspberries, gooseberries, currants (black, red and white), blueberries (European blueberry, wild bilberry, whortleberry, American blueberry), cranberries (American cranberry, European cranberry) and Berries nes (including inter alia: blackberry, loganberry, white, red mulberry, myrtle berry, hackberry, dangleberry).According to this data, statistical analysis of each kind of berry in the area of Europe has been done. In Figure 1, area harvested of strawberries in Europe in 2013-2017 is provided. There we can see that the common growers of strawberries in Europe are Poland, Russian 
J. Greblikaite, A. Ispiryan, D. Montvydaite. Development of Berry Farms in Europe: Organisational and Management Issues

Federation, Germany, Belarus and Ukraine. The biggest area harvested of strawberries in 2017 was in Poland (49642 ha), the smallest - in Luxembourg (7 ha). In most of the countries area harvested of strawberries in analysis period has decreased.

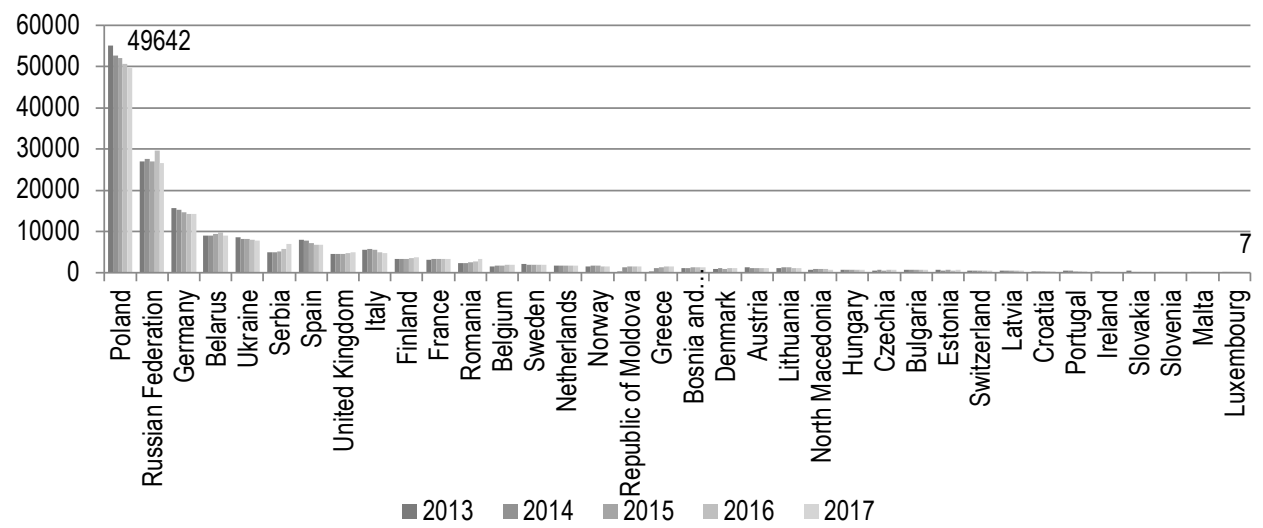

Source: (Food, 2019).

Figure 1. Area harvested of strawberries in Europe, 2013-2017, ha

In Figure 2, area harvested of raspberries in Europe in 2013-2017 is provided. It shows that the common growers of raspberries in Europe are Poland, Serbia, Russian Federation, Ukraine and Bosnia and Herzegovina. The biggest area harvested of raspberries in 2017 was in Poland (29317 ha), the smallest - in Luxembourg (1 ha). In most of the countries area harvested of raspberries in analysis period was swinging unstable, however, analysing the data of past few years, in most of the countries it has decreased.

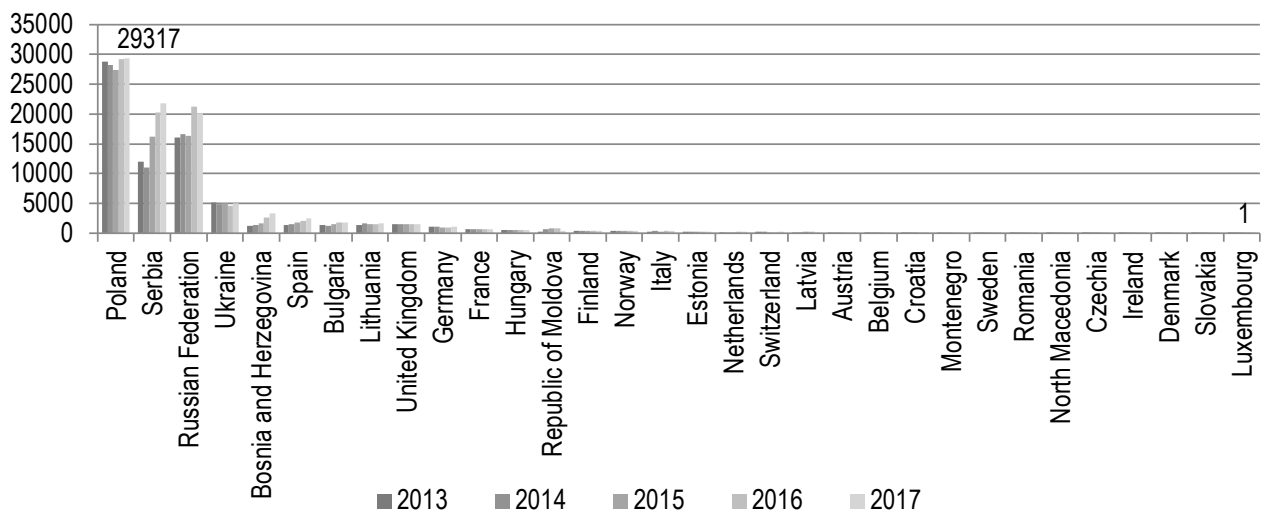

Figure 2. Area harvested of raspberries in Europe, 2013-2017, ha

Source: (Food, 2019).

Figure 3 shows harvested area of gooseberries in Europe in 2013-2017. It can be seen that the common growers of gooseberries in Europe are Germany, Russian Federation, Poland, Lithuania and Ukraine. The biggest harvested area of raspberries in 2017 was in Poland (12295 ha), the smallest - in 
J. Greblikaite, A. Ispiryan, D. Montvydaite. Development of Berry Farms in Europe: Organisational and Management Issues

Slovakia (0 ha). In most of the countries area harvested of gooseberries in analysis period was swinging unstable, however, there can be seen the decrease in the data of past few years.

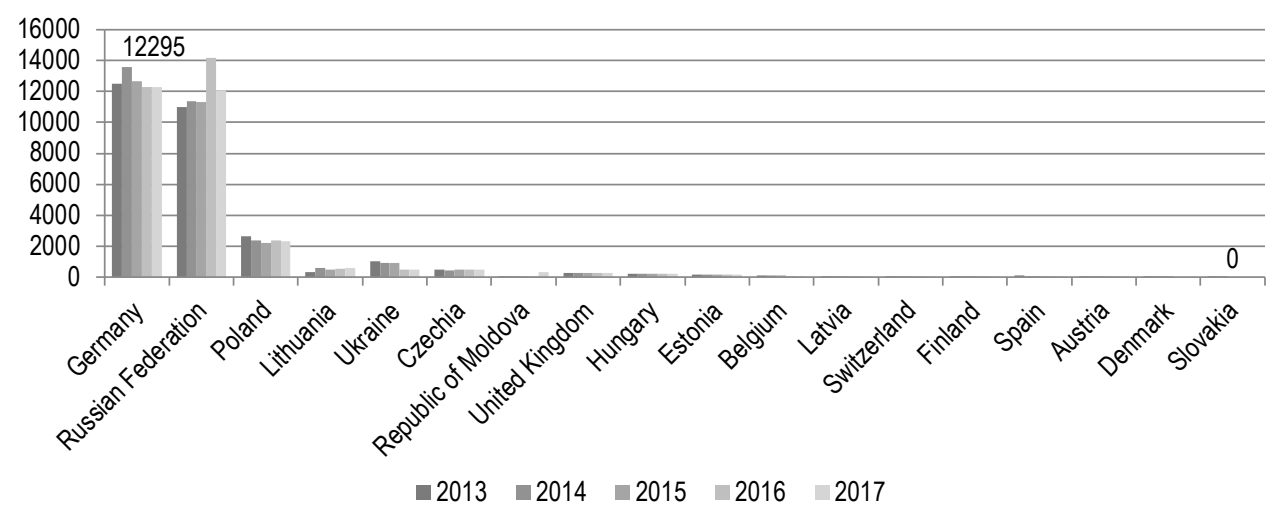

Figure 3. Area harvested of gooseberries in Europe, 2013-2017, ha

Source: (Food, 2019).

Figure 4 shows area harvested of currants in Europe in 2013-2017. There we can see that the common growers of currants in Europe are Russian Federation, Poland, Ukraine, France and United Kingdom. The biggest area harvested of raspberries in 2017 was in Russian Federation (48592 ha), the smallest - in Slovenia (1 ha). Area harvested of gooseberries in analysis period has been swinging quite unstable, however, in most of the countries it has not decreased sharply.

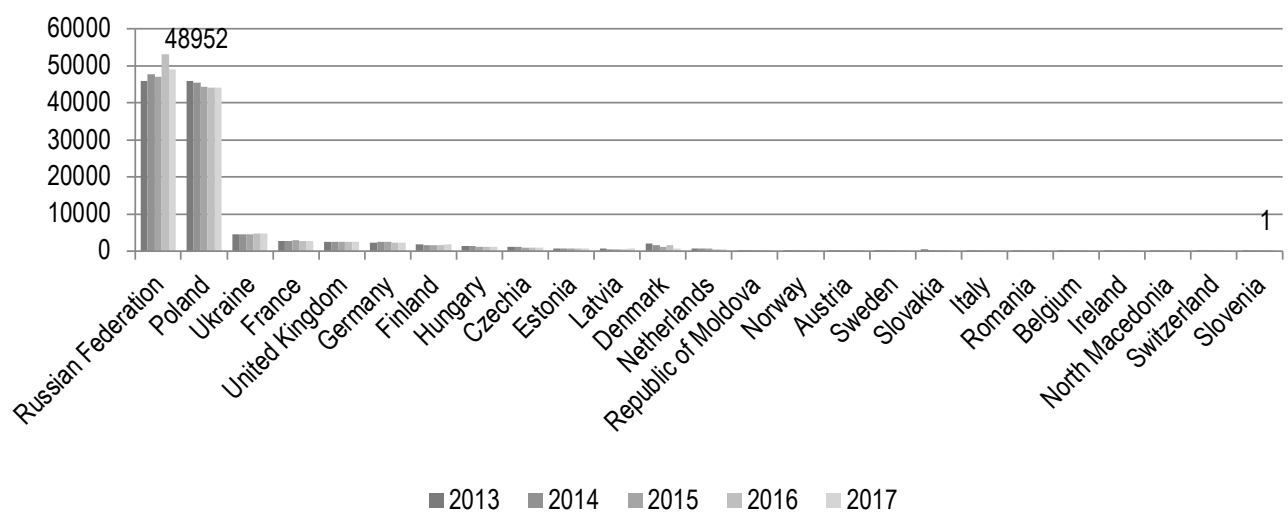

Figure 4. Area harvested of currants in Europe, 2013-2017, ha

Source: (Food, 2019)..

Figure 5 shows area harvested of blueberries in Europe in 2013-2017. There we can see that the common growers of blueberries in Europe are Poland, Spain, Germany, France and the Netherlands. The biggest area harvested of raspberries in 2017 was in Poland (5318 ha), the smallest - in Slovenia (13 ha). Area harvested of blueberries in analysis period was swinging individually in different countries. 
J. Greblikaite, A. Ispiryan, D. Montvydaite. Development of Berry Farms in Europe: Organisational and Management Issues

For example, Lithuania was one of the common growers of blueberries in Europe in 2013-2014. However, there was quite sharp decrease of area harvested in 2015, while in the same period there can be seen quite significant increase in data of Poland, Spain and Germany.

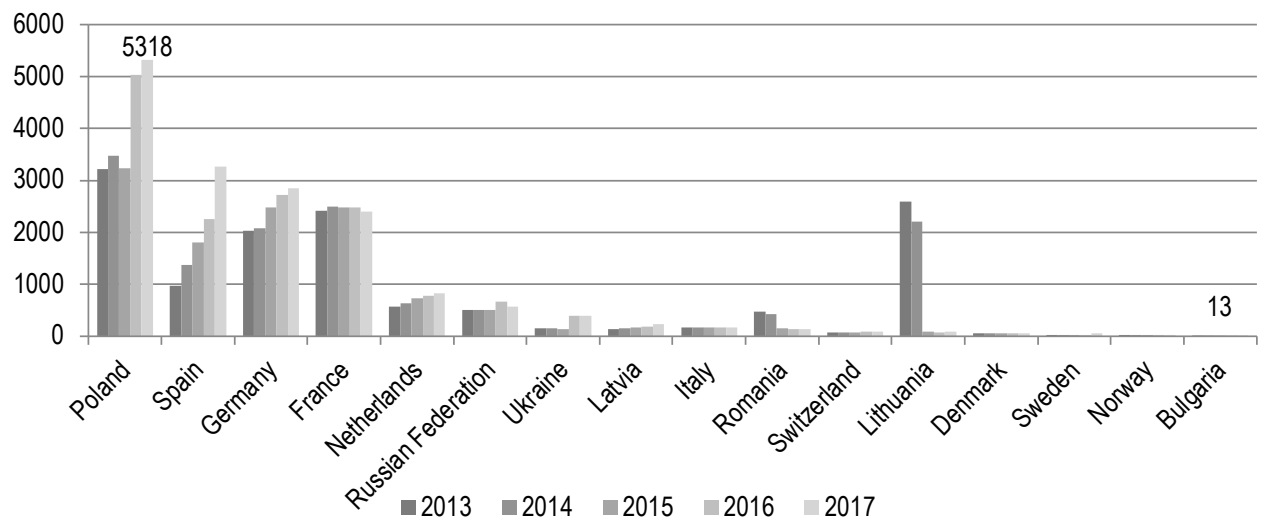

Figure 5. Area harvested of blueberries in Europe, 2013-2017, ha

Source: (Food, 2019).

In the Figure 6, we can see area harvested of cranberries in Europe in 2013-2017. It shows that the common growers of cranberries in Europe are Ukraine, Latvia, Belarus, Romania and Bulgaria. Comparing to other kind of berries analysed, amount of the area harvested of cranberries in Europe is the smallest. The biggest area harvested of raspberries in 2017 was in Poland and it was only 202 ha, the smallest was in Slovenia (51 ha). One of the sharper changes in analysis period was in Belarus, where in 2014 can be seen a significant decrease from the very top of the Europe cranberries growers to the outstanding position.

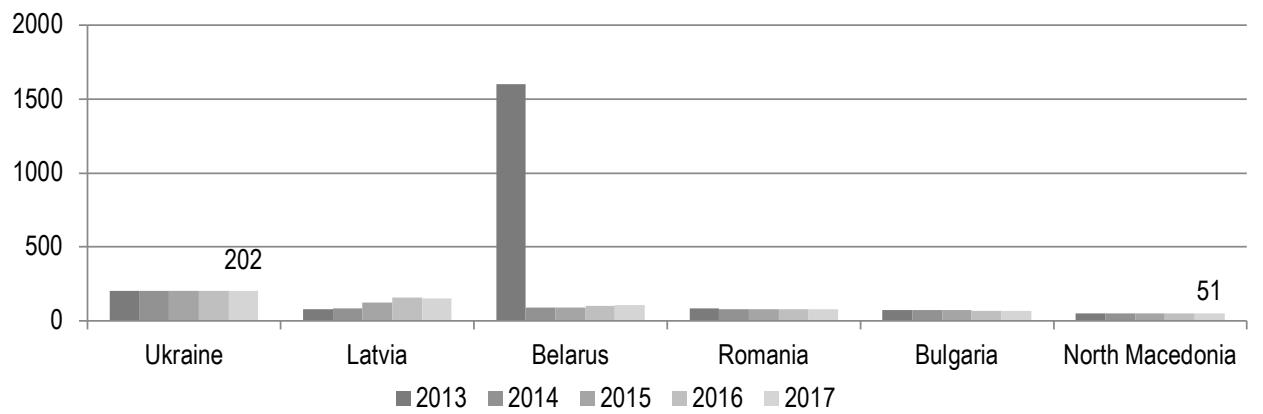

Figure 6. Area harvested of cranberries in Europe, 2013-2017, ha

Source: (Food, 2019).

In Figure 7, we can see area harvested of berries nes in Europe in 2013-2017. It shows that the common growers of berries nes in Europe are Poland, Lithuania, Italy, Germany and Estonia. The biggest area harvested of berries nes in 2017 was in Poland (12615 ha), the smallest - in Slovakia (16 ha). Area harvested of berries nes in analysis period did not have a stable tendency and was swinging individually in different countries. For example, there can be seen quite sharp increase in Poland and in 
J. Greblikaite, A. Ispiryan, D. Montvydaite. Development of Berry Farms in Europe: Organisational and Management Issues

Lithuania, while in Italy the area harvested of berries nes in analysis period has been tendencious decreasing.

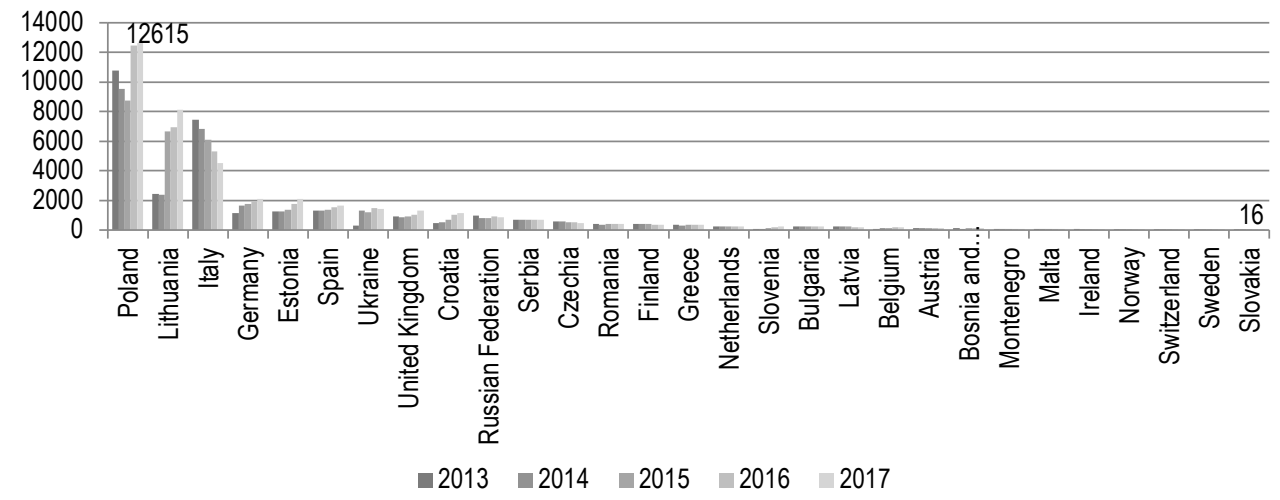

Figure 7. Area harvested of berries nes in Europe, 2013-2017, ha

Source: (Food, 2019).

Concluding data of the area harvested of all kind of berries in Europe that have been analysed, Poland could be mentioned as one of the main berry growers in Europe. It takes the leading position in growing strawberries, raspberries, blueberries and berries. Beside Poland, there is Russian Federation, Ukraine, and Germany that have quite significant part of area harvested of analysed kind of berries in Europe. What is more, Lithuania takes place in top five berry growers in area harvested of gooseberries and berries, that includes blackberry, loganberry, white, red mulberry, myrtle berry, hackberry, dangleberry. The top five berries growers in Europe can be seen in Table 1, which shows harvested area in 2017 in hectares by different kind of berries. There we can see that the biggest area harvested in Europe is taken by strawberries (161919 ha), currants (113514 ha) and raspberries (93022 ha). The table also reveals Europe countries specialization in growing berry. Although different countries are growing different kind of berries, there could be distinguished few countries that are the leaders in almost all kind of berries, according to area harvested. Those are Poland, Russian Federation, Ukraine and Germany. Assessing different kind of berries, Europe has biggest areas harvested of strawberries, raspberries and currants. Grey cells denote which countries have the biggest area harvested of analysed different kind of berries. There are highlighted five main countries harvesting the biggest area of each kind of berries. For a wider perception, it could be mentioned that apart from the agricultural land, there are large areas of wild collection in Europe, 13 million hectares in total. The largest areas of berries are in Finland, followed by several South Eastern European countries. Whereas, for most permanent crops, the EU-15 countries have the largest areas, the EU-13 countries have considerable areas of temperate fruits (e.g., apples in Poland) and berries in the Baltic countries (Willer et al., 2015). However, the biggest amount of berries production is generated in berry farms.

Table 2 shows the yield of different kind of berries in Europe countries in 2017 by hectograms in hectare. There we can see that the biggest amount of yield in Europe in 2017 was in strawberries (4888077 hg/ha), raspberries (2043647 hg/ha) and berries nes (1081923 hg/ha). Grey cells denote which countries have the biggest amount of yield evaluating different kind of berries. The table reveals that the most productive harvested areas of berries in Europe are in different countries according to different kind of berries. 
J. Greblikaite, A. Ispiryan, D. Montvydaite. Development of Berry Farms in Europe: Organisational and Management Issues

Table 1. Area harvested of berries in Europe, 2017, ha

\begin{tabular}{|c|c|c|c|c|c|c|c|}
\hline $\begin{array}{c}\text { Country I } \\
\text { Berries }\end{array}$ & Strawberries & Raspberries & Gooseberries & Currants & Blueberries & Cranberries & $\begin{array}{c}\text { Berries } \\
\text { nes }\end{array}$ \\
\hline Austria & 1140 & 176 & 12 & 259 & - & - & 155 \\
\hline Belarus & 9063 & - & - & - & - & 106 & - \\
\hline Belgium & 1976 & 170 & 65 & 78 & - & - & 177 \\
\hline $\begin{array}{l}\text { Bosnia and } \\
\text { Herzegovina }\end{array}$ & 1335 & 3296 & - & - & - & - & 106 \\
\hline Bulgaria & 655 & 1863 & - & - & 13 & 68 & 230 \\
\hline Croatia & 371 & 169 & - & - & - & - & 1171 \\
\hline Czechia & 687 & 27 & 473 & 860 & - & - & 496 \\
\hline Denmark & 1165 & 17 & - & 622 & 59 & - & - \\
\hline Estonia & 654 & 274 & 139 & 813 & - & - & 2092 \\
\hline Finland & 3803 & 429 & 28 & 1740 & - & - & 351 \\
\hline France & 3407 & 670 & - & 2700 & 2394 & - & - \\
\hline Germany & 14156 & 1072 & 12295 & 2338 & 2844 & - & 2123 \\
\hline Greece & 1470 & - & - & - & - & - & 333 \\
\hline Hungary & 735 & 590 & 189 & 1195 & - & - & - \\
\hline Ireland & 189 & 24 & - & 40 & - & - & 56 \\
\hline Italy & 4855 & 359 & - & 150 & 174 & - & 4500 \\
\hline Latvia & 489 & 187 & 41 & 635 & 236 & 153 & 194 \\
\hline Lithuania & 1109 & 1632 & 599 & - & 85 & - & 8134 \\
\hline Luxembourg & 7 & 1 & - & - & - & - & - \\
\hline Malta & 50 & 159 & - & - & - & - & 76 \\
\hline Netherlands & 1691 & 250 & - & 517 & 832 & - & 257 \\
\hline Norway & 1536 & 405 & - & 287 & 20 & - & 55 \\
\hline Poland & 49642 & 29317 & 2334 & 44041 & 5318 & - & 12615 \\
\hline Portugal & 314 & - & - & - & - & - & - \\
\hline Moldova & 1481 & 459 & 303 & 338 & - & - & - \\
\hline Romania & 3250 & 40 & - & 150 & 130 & 80 & 414 \\
\hline $\begin{array}{c}\text { Russian } \\
\text { Federation }\end{array}$ & 26565 & 20185 & 12089 & 48952 & 577 & - & 837 \\
\hline Serbia & 7054 & 21861 & - & - & - & - & 700 \\
\hline Slovakia & 143 & 9 & - & 190 & - & - & 16 \\
\hline Slovenia & 108 & - & - & 1 & - & - & 231 \\
\hline Spain & 6819 & 2482 & 20 & - & 3260 & - & 1626 \\
\hline Sweden & 1970 & 130 & - & 240 & 50 & - & 20 \\
\hline Switzerland & 524 & 193 & 41 & 5 & 93 & - & 23 \\
\hline $\begin{array}{c}\text { North } \\
\text { Macedonia }\end{array}$ & 807 & 28 & - & 11 & - & 51 & - \\
\hline Ukraine & 7800 & 5000 & 500 & 4800 & 400 & 202 & 1400 \\
\hline $\begin{array}{c}\text { United } \\
\text { Kingdom }\end{array}$ & 4899 & 1548 & 289 & 2552 & - & - & 1292 \\
\hline In all & 161919 & 93022 & 29417 & $\begin{array}{c}11351 \\
4\end{array}$ & 16485 & 660 & 39680 \\
\hline
\end{tabular}

Source: (Food, 2019)

For example, the most productive areas comparing by growing different kind of berries have Russian Federation, Belgium, Netherlands, Spain and Ukraine, that are successfully growing three of four kind of berries. They generate the biggest amount of yield of berries measuring by hg/ha. Comparing the 
J. Greblikaite, A. Ispiryan, D. Montvydaite. Development of Berry Farms in Europe: Organisational and Management Issues

amount of yield of berries by countries, there can be highlighted Belgium, Greece, Ireland, Netherlands, Spain, Switzerland and United Kingdom that generate the biggest amount of yield of berries in general.

Table 2. Yield of berries in Europe, 2017, hg/ ha

\begin{tabular}{|c|c|c|c|c|c|c|c|}
\hline $\begin{array}{c}\text { Country I } \\
\text { Berries }\end{array}$ & Strawberries & Raspberries & Gooseberries & Currants & Blueberries & Cranberries & $\begin{array}{c}\text { Berries } \\
\text { nes }\end{array}$ \\
\hline Austria & 101465 & 62614 & 53857 & 114402 & 77559 & - & 57548 \\
\hline Belarus & 88023 & - & - & - & - & 26792 & - \\
\hline Belgium & 240385 & 175824 & 58462 & 75491 & - & - & 37627 \\
\hline $\begin{array}{l}\text { Bosnia and } \\
\text { Herzegovina }\end{array}$ & 73386 & 68781 & - & - & - & - & 73093 \\
\hline Bulgaria & 81817 & 40129 & - & 6559 & - & 12489 & 12263 \\
\hline Croatia & 86496 & 8209 & - & - & - & - & 12306 \\
\hline Czechia & 41137 & 9863 & 47191 & 18714 & - & - & 17814 \\
\hline Denmark & 57871 & 81176 & - & 53135 & 6729 & - & - \\
\hline Estonia & 20015 & 5985 & 10072 & 5412 & - & - & 2729 \\
\hline Finland & 36448 & 24965 & 17143 & 10851 & - & - & 8632 \\
\hline France & 173918 & 58723 & - & 36111 & 37235 & - & - \\
\hline Germany & 95566 & 59272 & 70340 & 53336 & 48541 & - & 35111 \\
\hline Greece & 400680 & - & - & - & - & - & 31107 \\
\hline Hungary & 70558 & 26932 & 37037 & 32728 & - & - & - \\
\hline Ireland & 349206 & 141667 & - & 55000 & - & - & 29680 \\
\hline Italy & 258157 & 63426 & - & 53467 & 97017 & - & 66667 \\
\hline Latvia & 28507 & 8182 & 2195 & 6567 & 14958 & 25670 & 10685 \\
\hline Lithuania & 24220 & 11495 & 3218 & - & 14588 & - & 7418 \\
\hline Luxembourg & 57143 & 10000 & - & - & - & - & - \\
\hline Malta & 187847 & - & - & - & - & - & 19693 \\
\hline Montenegro & - & 31472 & - & - & - & - & 55711 \\
\hline Netherlands & 390893 & 260114 & - & 34721 & 104930 & - & 53506 \\
\hline Norway & 55221 & 73827 & - & 24216 & 1500 & - & 22182 \\
\hline Poland & 35841 & 35639 & 40518 & 29247 & 30731 & - & 42324 \\
\hline Portugal & 297675 & - & - & - & - & - & - \\
\hline Moldova & 47536 & 18108 & 1448 & 3718 & - & - & - \\
\hline Romania & 83046 & 17500 & - & 5333 & 23846 & 70413 & 76233 \\
\hline $\begin{array}{c}\text { Russian } \\
\text { Federation }\end{array}$ & 66121 & 72519 & 48431 & 71764 & 50701 & - & 41988 \\
\hline Serbia & 42680 & 50200 & - & - & - & - & 42909 \\
\hline Slovakia & 54965 & 18889 & - & 2000 & - & - & 70139 \\
\hline Slovenia & 156111 & - & - & 44303 & - & - & 35887 \\
\hline Spain & 528547 & 175379 & 18000 & - & 108451 & - & 68498 \\
\hline Sweden & 79898 & 33077 & - & 15000 & 14000 & - & 10000 \\
\hline Switzerland & 181115 & 164751 & 135269 & 126704 & 36500 & - & 47702 \\
\hline $\begin{array}{c}\text { North } \\
\text { Macedonia }\end{array}$ & 64511 & 60000 & & 75067 & - & 61336 & - \\
\hline Ukraine & 70564 & 68320 & 156400 & 56542 & 34000 & 23318 & 9429 \\
\hline $\begin{array}{c}\text { United } \\
\text { Kingdom }\end{array}$ & 260508 & 106609 & 87929 & 54463 & - & & 83042 \\
\hline In all & 4888077 & 2043647 & 787510 & 1064851 & 701286 & 220018 & 1081923 \\
\hline
\end{tabular}

Source: Source: (Food, 2019). 
J. Greblikaite, A. Ispiryan, D. Montvydaite. Development of Berry Farms in Europe: Organisational and Management Issues

Table 3 shows production quantity of analysed kind of berries in Europe countries in 2017, by tonnes. There we can see that the biggest amount of production is generated from strawberries (1655189 t), currants (563655 t) and raspberries (539732 t).

Table 3. Production quantity of berries in Europe, 2017, $t$

\begin{tabular}{|c|c|c|c|c|c|c|c|}
\hline $\begin{array}{c}\text { Country I } \\
\text { Berries }\end{array}$ & Strawberries & Raspberries & Gooseberries & Currants & Blueberries & Cranberries & $\begin{array}{c}\text { Berries } \\
\text { nes }\end{array}$ \\
\hline Austria & 11567 & 1102 & 62 & 2963 & - & - & 892 \\
\hline Belarus & 79778 & - & - & - & - & 284 & - \\
\hline Belgium & 47500 & 2989 & 380 & 589 & 99 & - & 666 \\
\hline $\begin{array}{l}\text { Bosnia and } \\
\text { Herzegovina }\end{array}$ & 9793 & 22671 & - & - & - & - & 774 \\
\hline Bulgaria & 5359 & 7476 & - & - & - & 85 & 282 \\
\hline Croatia & 3209 & 138 & - & - & - & - & 1441 \\
\hline Czechia & 2827 & 27 & 2231 & 1609 & - & - & 884 \\
\hline Denmark & 6742 & 138 & - & 3305 & 40 & - & - \\
\hline Estonia & 1309 & 164 & 140 & 440 & - & - & 571 \\
\hline Finland & 13861 & 1071 & 48 & 1888 & - & - & 303 \\
\hline France & 59260 & 3936 & - & 9750 & 8916 & - & - \\
\hline Germany & 135283 & 6354 & 86480 & 12470 & 13805 & - & 7454 \\
\hline Greece & 58900 & 70 & - & - & - & - & 1037 \\
\hline Hungary & 5186 & 1589 & 700 & 3911 & - & - & - \\
\hline Ireland & 6600 & 340 & - & 220 & - & - & 167 \\
\hline Italy & 125335 & 2277 & - & 802 & 1690 & - & 30000 \\
\hline Latvia & 1394 & 153 & 9 & 417 & 353 & 393 & 207 \\
\hline Lithuania & 2686 & 1876 & 193 & - & 124 & - & 6034 \\
\hline Luxembourg & 40 & 1 & - & - & - & - & - \\
\hline Malta & 934 & - & - & - & - & - & 149 \\
\hline Montenegro & - & 500 & - & - & - & - & 500 \\
\hline Netherlands & 66100 & 6500 & - & 1795 & 8729 & - & 1374 \\
\hline Norway & 8482 & 2990 & - & 695 & 3 & - & 122 \\
\hline Poland & 177921 & 104482 & 9457 & 128808 & 16343 & - & 53392 \\
\hline Portugal & 9347 & 17880 & - & - & 9840 & - & 618 \\
\hline Moldova & 7041 & 832 & 44 & 126 & - & - & - \\
\hline Romania & 26990 & 70 & - & 80 & 310 & 561 & 3156 \\
\hline $\begin{array}{c}\text { Russian } \\
\text { Federation }\end{array}$ & 175652 & 146377 & 58551 & 351304 & 2928 & - & 3513 \\
\hline Serbia & 30106 & 109742 & - & - & - & - & 3003 \\
\hline Slovakia & 786 & 17 & - & 38 & - & - & 112 \\
\hline Slovenia & 1686 & - & - & 3 & - & - & 829 \\
\hline Spain & 360416 & 43529 & 36 & 900 & 35355 & - & 11137 \\
\hline Sweden & 15740 & 430 & - & 360 & 70 & - & 20 \\
\hline Switzerland & 9490 & 3180 & 555 & 63 & 339 & - & 112 \\
\hline $\begin{array}{c}\text { North } \\
\text { Macedonia }\end{array}$ & 5206 & 168 & - & 80 & - & 312 & - \\
\hline Ukraine & 55040 & 34160 & 7820 & 27140 & 1360 & 472 & 1320 \\
\hline $\begin{array}{c}\text { United } \\
\text { Kingdom }\end{array}$ & 127623 & 16503 & 2538 & 13899 & - & - & 10729 \\
\hline In all & 1655189 & 539732 & 169244 & 563655 & 100304 & 2107 & 140798 \\
\hline
\end{tabular}

Source: Source: Source: (Food, 2019). 

Issues

What is more, the table reveals obvious leaders of berries production. The leading countries that produce the biggest amount of berries production are Germany, Poland, Russian Federation, Spain, Ukraine and United Kingdom. These countries are leaders in almost all kind of berries that has been analysed. The biggest amount of strawberries and blueberries production is gained in Spain, Russian federation produces the biggest number of raspberries, Germany specializes in producing currants and Poland is producing the biggest number of berries. In general, there is not a very significant quantity of production of cranberries in Europe, but measuring just this kind of berries, the main part of production is gained in Romania. To conclude all results after evaluation of area harvested, yield and production of berries, it has been revealed that the leading countries in Europe in berry farming are Poland, Russian Federation, Ukraine, Germany and Spain. Poland is the biggest producer of strawberries, Russian Federation generates the biggest amount of currants production, Ukraine produces significant amount of raspberry production, Germany and Spain are also specializing in strawberry production, comparing to other kind of berries. Tu sum up the amount of production by different kind of berries, there are produced the biggest amount of strawberries, raspberries and currants production in Europe. In order to find out what are the possibilities of berry farming development, more detailed analysis of the berry farming and its management in the biggest berries' producers' countries in Europe should be done. When talking about berry farm's development, it is important not just to ensure the best harvesting conditions and concentrate into amount of the yield, but the other main question is how to create value, i.e. what type and condition berries to produce, what high value added products to make and how to meet the consumers' demand and sell production in competitive market.

A real challenge for the berry producers is to better utilise the tools of marketing. As Michal et al. (2018) claim, market tools are highly preferred voluntarily in order to protect nature and create ecological goodwill in society, so it is important not only for competitiveness, but also for environmental aspects. It is claimed that opportunities for market segmentation can be significant and should not be ignored or assumed. The more limited the marketing resources are, the more important it is to target them. Consumer insight is an essential ingredient for successful product and market development (Invenire Market Intelligence, 2018). Farrugia et al. (2015) claims that, knowing the behaviour and motivations of consumer purchasing is very important for the production and distribution companies; so, they can establish effective marketing strategies by maintaining and even increasing share of domestic and international market. Over the past few decades, there has been a steady increase in the demand for fruit and fruit-based products, as consumers seek out healthier dietary options (Tefera et al., 2018). Sedik et al. (2018) affirm that many consumers are attracted by healthy lifestyle and healthy eating habits in order to maintain their health. Lefevrea et al. (2011) agree that berries have gained attention because of their potential for improving human health. The authors claimed that berry fruits, consumed fresh or processed, are nutritionally valuable food, as they are rich sources of minerals, vitamins, sugars, dietary fibres, organic acids and polyphenolic compounds. Baby et al. (2018) adds that berries are excellent sources of natural antioxidants and represent an important component of healthy diet. Apart from already mentioned vitamins, minerals, sugars, and fibers, they are rich in bioactive compounds including phenolics, flavonoids, and tannins. These phytochemicals have been reported to possess anticancer and antioxidant activities (Castro et al., 2015). Consequently, the inclusion of fresh produce in the human diet has been steadily increasing due to heightened consumer awareness of the associated health benefits (Falco et al., 2019). Research made by Invenire Market Intelligence (2018), revealed that the issues that seem to be increasingly important for consumers are packaging, provenance and health benefits. Bhat et al. (2015) agreed that today, consumers tend to give high priority for a wide array of aspects relevant to nutritional composition, sensory qualities, and safety in fresh produce. According to Vittori et al. (2018), consumer quality acceptance is generally related to specific perceived organoleptic traits such as fruit colour, shape, acidity and sweetness, combined with flavour and aroma determined 

Issues

by volatile compounds. Authors (Vittori et al., 2018) claimed that, usually, fruits with a brighter colour are more appreciated by the consumer than paler fruits. For new consumer trends the firmer and crunchier the fruit the more appreciated it is in comparison to a softer and juicy fruit. Finally, flavour is one of the main attributes that the consumer appreciates in berries, and that can influence the consumer's acceptance. To sum up, consumers' acceptance, expectations, and preference for high quality fruits are vital criteria, which are all highly essential to monitor production, transportation, and marketing of food commodities (Bhat et al., 2015). Summarizing all analysed scientists" research it could be concluded that berry growers has the real challenge to meet the consumers' needs and to remain in the competitive market.

According to Vittori et al. (2018), if for several years, the agronomic and organoleptic qualities were the main drivers of the market choice for berries, nowadays the importance of fruit nutritional value is strongly increasing mainly because of increased awareness of the consumers on the health effects related to the berry consumption. It is for this reason that recent breeding programs are focusing increasingly their attention on the identification of new cultivars combining plant resilience with yield and enhancement of fruit sensorial and nutritional quality. Research by Invenire Market Intelligence (2018) illustrated that the berry market rides the crest of a wave. Berries meet the many requirements of the market, like those related to health, taste, and convenience. Therefore, there are good opportunities for further growth. Berries are normally consumed fresh or in frozen/processed form (Nile et al., 2014). Research carried out by Invenire Market Intelligence (2008) revealed that berry ingredients (purees, pieces, powders, extracts, etc) are important drivers for the berry market development. An explanation is that in processed forms, berries are made available for consumers in more convenient forms. Hoverer, fresh berries is a global and highly competitive market. Berry companies are working on 52 week availability, global sourcing, environmental issues, and increased consumer awareness and demand (Invenire Market Intelligence, 2008). According to Tefera et al. (2018), consumer demand for fresh berries is increasing, resulting in the production and import of greater volumes of berries, and this trend is expected to persist into the foreseeable future. For example, the United Kingdom is one of the biggest markets for berry sales, and over the last decade, sales here alone have risen by $132 \%$. In the United States, raspberry and blueberry consumption has risen by $411 \%$ and $475 \%$, respectively (Barro, 2014). In addition to the increase in fresh berry consumption in many countries, we are also consuming increasing numbers of berries in other forms, such as smoothies and shakes (Tefera et al., 2018). Baltic (frozen) berries can be found in juices or yogurts all over Europe (Willer et al., 2015). The compound annual growth rate of the smoothie market is envisaged to exceed 7\% from 2016 to 2020 (Statista, 2015). According to the research of Invenire Market Intelligence (2008), the future for healthy nutrition and functional foods will be dominated by beverage concepts. Consumers are increasingly looking to beverages of all kinds to deliver health benefits - berries are in a good position to exploit this demand.

The enhanced consumer demand for berries has increased their cultivation. Raspberry production has benefited from this trend, although production of other fresh berries, such as blueberries and blackberries, has also grown tremendously during the last few decades. Many of the countries in which berry production is on the rise are those with warm climates, to ensure year-round production, and often have cheap labour costs (Tefera et al., 2018). Farmers are taking up to grow berries because, as Zbanca et al. (2018) claimed, production of berries allows for highest profits and presents a major potential for increasing the income of small farmers and diversifying the sources of income in rural areas. Although berries may be grown on a large-scale, it is also common that they are grown on small production sites (Tefera et al., 2018). Zbanca et al. (2018) argued that currently, agricultural entrepreneurs aim at developing high value agriculture (HVA), while small and young entrepreneurs show a high interest in the production of berries, as this allows to obtain a high profit on small areas while ensuring an efficient business management. According to Guerrino et al. (2018), berries can be 

Issues

produced in exclusive or shared cultivations, and the size of the farms can vary from large - to small scale, based on the production requirement. The fruits are often consumed after minimal processing, and the production consists of various approaches and culturing techniques, including cultivation in soil, in pots, by hydroponic technologies, in open fields, and in greenhouses. Talking about harvesting, there is also used different kind of techniques in different countries. For example, in berry production on-farm, food handlers picked berries with their bare hands (in Poland, Serbia), with gloved hands (in Finland, the Czech Republic) or mechanically (in Serbia) (Maunula et al., 2013). To sum up, there are different ways of managing berry farming, so willing to succeed in berry production, it is very important to analyse different aspects of berry farm management to find the best solution for development.

What is more talking about berry farming management, Zbanca et al. (2018) claimed that the development of agricultural businesses should be based on competitiveness of products, assurance of quality and compliance with marketing requirements according to the demands of the end consumer. The authors (Zbanca et al., 2018) argued that the market economy requires that agricultural producers guide their business by maintaining a business, which meets and observes the following important issues: implementation of modern and intensive technologies, development of product value chain, practice of commercial agriculture, development of marketing infrastructure, association in professional organizations based on common interest and homogeneous products, cooperation to promote and penetrate new favourable markets, etc. Research made by Invenire Market Intelligence (2018) confirmed that even though many berry companies are working in niche markets, they need to allocate enough resources for R\&D, distribution and particularly marketing. A way forward is to collaborate with others, and jointly try to address some of the issues, like e.g. creating increased awareness and public interest for the chosen berries. According to Zbanca et al. (2018), the farmers who intend to develop a business focused on production of berries need to consider the following major issues: - whether the selected fruit(s) and technology allow ensuring quality, productivity and ultimately competitiveness; - production of competitive berries is a key element for marketing on regional markets (where the end consumer should be identified immediately and the technology needs to be adjusted to meet the customer's needs in the product); - only the quality/competitiveness will allow to compete and sell such products on the strategic berry sales markets. As the research of the Invenire Market Intelligence (2008) claimed, a successful strategy for many berries is a niche strategy where companies try to command high value and low volume market niches through health platforms, novelty and convenience. It is accrued that companies involved with berries can choose from many different commercialisation strategies. They can work with fresh berries, beverages, ingredients, cosmetics or dietary supplements. It can be added that the more versatile the strategies are - the better are the companies' possibilities to succeed on the market.

Perea et al. (2017) argued that nowadays the pressure exerted on the agricultural sector by public administrations and clients to shift production from a focus on quantity to a focus on sustainability and quality is increasing. For these reasons farmers face with a difficult challenge: to carry out a verifiable efficient use of resources reducing environmental impacts while maintaining or even increasing their profit. According to Zbanca et al. (2018), berry producers need to identify the most relevant and optimal answers to the questions below in order to manage their business in an efficient and sustainable way: Do they have all the production factors required for berry cultivation (irrigation, adequate land, labour force, knowledge)?; - Which is the end consumer and segment in the sales market (processing, sales in a market or supermarket)?; - Analysis of supply and demand of berries on a monthly basis for finding own niche; - Distance from the sales market and selection of the crops (degree of perishability, ripening time, etc.); - Ensuring the harvesting and sales conveyor, which allows for more efficient management of the business; - Selection of the crops and selection of cultivation technology; - Proper information on berry crop cultivation, access to a flow of specialized information and technology transfer in the sector; Feasibility study and business plan for business and accumulation of economic data and analyses for 

Issues

correct and efficient decision-making; - Optimal harvesting time, correct harvesting methods, produce conditioning, adequate packaging; - The need and willingness to invest in cultivation and to develop the value chain for berries in order to minimize risks and create added value in price; - Producer's willingness to associate and cooperate - these two prerequisites provide real possibilities for practicing a sustainable berry business. What is more talking about successful berry farming management, Perea et al. (2017) added that the farmer's general rule is to use inputs as much as possible (e.g. water, fertilizers, pesticides) to avoid yield losses, when there are not financial restrictions. Zbanca et al. (2018) accrued that high value production is a way to obtain a higher profit. There are two subsectors: the fresh and processed berry subsectors. The processed berry sector also includes four major groups of products: preserved, dried, frozen berries and juices. The production of fresh berries for the market provides the highest value for farmers, making it the most profitable, if the high quality of the product is ensured throughout the entire value chain and if the deliveries are ensured for a longer period. The production of berries for the processing industry offers lower incomes to farmers. However, the requirements for fruit quality are also lower, and thus lower production costs are incurred (Zbanca et al., 2018). According to Vittori et al. (2018), long term breeding programmes can lead to the release of more improved cultivars that are able to adapt to different climatic conditions and cultivation systems by maintaining high quality standards even at long distance commercialization of fresh product. The authors (Vittori et al., 2018), claimed that in the last decades, breeding programs on fruit plants focused their priorities on the diffusion of new berry cultivars adapted to different climatic conditions and cultivation systems, with high yield, fruit size an firmness, resistance to pathogens and transport damages, and longer shelf life. Feliziani et al. (2016) accrued that the goal for the breeders is the obtainment of the new cultivars with highly resilient plants, to low input cultivation systems and high adaptability to future climate scenarios, and able to bear high yields of organoleptic and nutritional quality fruits. Vittori et al. (2018) agree that the real peculiarity of berries is their adaptability to different climatic conditions, from very warm to very cold climates. Some berry species reveal significant adaptability to different pedoclimatic conditions; in those cases, the quality of their fruits can be closely influenced by their growing location, in open feels conditions. For example, Kruger et al. (2012) demonstrated that the same strawberry cultivars grown in northern Europe can produce fruit with higher commercial and organoleptic traits, such as increased dry matter, total acidity and soluble solids content compared to those grown in southern Europe.

Analysing the situation in Europe countries berry farming, for example, in case of berry production, in the Republic of Moldova in the bacciferous crop sector, the biggest challenge that domestic producers face is the need to increase the competitiveness, which primarily requires upgraded technologies (the yield per hectare is low) and higher economic efficiency (Zbanca et al., 2018). Studying the scientific literature, it is found that researching berry farm's management scientists are talking about yield efficiency. According to Vittori et al. (2018), plant yield is the first parameter that a grower takes into consideration in the decision to grow a new cultivar. Furthermore, the harvesting facility is another important parameter, which indicates if a cultivar can reduce labour costs, the most important cost for all berries. Clearly of high importance is plant adaptability to different pedo-climatic conditions and resistance to pest and pathogens. These traits are the priority to reduce inputs and increase plant yield efficiency. Concluding, there were analysed general researches of the scientists and all the insights are very significant trying to find the best solutions of developing berry farms. It was found that there are a lot of different parameters that affects successful berry farming. The main parameters are yield efficiency, added value creation and meeting the consumers' demand in order to production realization. However, for conclusions substantiation, it is also important to explore the situation in different countries of Europe, especially in those, which are established to be the biggest berry producers and could be found as an example of good practice for the berry farming solutions in Lithuania. Poland is found to be one of the 

Issues

biggest berry producers in Europe according to the past few year statistics. It is a leading grower/producer of berries that are either eaten raw or processed. Amongst the many small plantations that are thriving in this country, there are many multi-hectare ones growing black/redcurrants, strawberries, raspberries, forest fruits and cranberries. Cultivating berries in Poland forms an important and dynamic part of fruit farming industry (Matyaszek et al., 2012). During recent years Poland has become one of the largest raspberry producers in the world. The high quality of Polish raspberry fruits is a result of a combination of favourable climatic and soil conditions as well as advanced technologies. Most of the raspberry fruits harvested in Poland are used for industrial purposes and the processed raspberries are well-known in European countries (Gugala et al., 2015). Poland farmers are also growing black raspberries. They have good substances and health benefits. Therefore, black raspberry, little known in central Europe, but with the potentially huge health-beneficial value, should be considerably better promoted. Likewise, these blackberry cultivars that are genetically better adapted to the central European conditions deserve to become more popular in this region (Gugala et al., 2015). Matyaszek et al. (2012) analysed the elements of successfully berry farming in Poland. The author claimed that in order to secure successful crop harvests it is necessary to have healthy seedlings and that the land is fit for its intended use. Profitability of harvests mainly depend on plantation size and fruit yield. Beside raspberries, it is important to analyse strawberries production aspects as it is the most common kind of berries produced in Europe (1655189 t per 2017 year). Juan et al. (2016) claims that Europe produces $22 \%$ of the world's strawberries. Most provenances are from Romania, Poland, Italy and Spain. According to the Food and Agriculture Organization (FAO) of the United Nations, the world production of strawberries, has exceeded four million tons since 2007. Today the biggest amount of strawberries in Europe is produced in Spain (360416 t per 2017 year). Lozano et al. (2016) add that in south-west of Spain, the strawberry crop generates high economic value goods and high rate of employments. In general, amid a wide array of fruits available in the international market, strawberry has gained high praise among consumers for its unique taste and health benefits. Strawberries are also in great demand in food industries, wherein they are widely used as flavouring agents, as well as a key ingredient in preparation of jam, juice, or jellies (Bhat et al., 2015). Strawberries are one of the most widely consumed berry fruits in the world (Export Opportunity Surveys, 2017). Talking about strawberry cultivation, it is important to mention that, as most of the drawbacks endured during various stages of processing (preor post-harvest stages) of strawberries can affect consumers' preferences and purchasing behaviour, it is highly imperative to identify the major hindrances to help dependent farmers and industry (Bhat et al., 2015). According to the research carried out by Export Opportunity Surveys (2017), strawberries are grown in various regions around the world, as they tolerate different soil types. They are harvested by hand at least three times a week when they reach ripeness. What is more, strawberries must be harvested and hand-picked at the right time and handled properly in order to remain in good condition for several days. Proper post-harvest handling of strawberries is also important.

As Germany is also one of the biggest strawberries' producers, it could be mentioned that today, the majority of dependent families on strawberry farming in Germany is on the rise (Bhat et al., 2015). Talking about berry production management, there are two main value chains that are used in practice in Germany: the first one is when the handler picks up and pack fresh strawberries then distribute them to wholesale markets and the second one is when using Pick-Your-Own system, when the product flows directly from producers to end consumers eliminating the need for intermediaries. It was established that in Germany, around 35\% of the strawberry production is sold directly to customers via farm shops and roadside stand (Export Opportunity Surveys, 2017). When talking about Germany berry farming, it is important to discuss organic farming. In general, organic sector of agrarian business continues to expand worldwide therefore organic food production and consumption have increased in the European Union (EU). The countries with the largest organic markets in the EU are Germany, France, and Italy 

Issues

(Bezus et al., 2018). According to Willer et al. (2018), the EU's organic market in 2016 was the second largest in the world after the United States' and accounted for $37 \%$ of the world organic market that year. Its volume amounted to 30.7 billion euros, which is $11 \%$ more than in the previous year. Coming back to Germany's strawberry market and organic farming, according to research by Export Opportunity Surveys (2017), domestic production there has increased over the past four years while the amount of organically produced strawberries has declined. According to Bezus et al. (2018), actual problems of small organic agribusiness are the lack of financial, credit, and resource support. Issues of products' certification and standardization, the search for effective selling channels remain important. That may be the reasons why farmers do not practice organic farming willingly. According to research by Export Opportunity Surveys (2017), for most consumers, farming practices are not important, however, $35 \%$ of Germany consumers buy organic strawberries. In addition to this, Germany has a much lower production capacity and does not export any organic strawberries as consumer demand exceeds domestic production. What is more, Germany is the biggest producer of gooseberries ( 86480 tonnes per 2017 year). According to Velioglu et al. (2002), strong consumer demand for fruit products and dietary supplements provide opportunities for gooseberry commercialization. Talking about gooseberries production, they are generally used for jams, jellies, pastries, and deserts. Their resemblance to grapes in taste, texture, and size may allow them to substitute for table grapes in niche markets. Moreover, gooseberries are also sold canned for use in pastry fillings and other dessert applications (Velioglu et al., 2002). Analysing another one's of the biggest berries producers in Europe, Ukraine's berry farming, it can be mentioned that in 2018, Ukrainian consumers also more often choose organic products than in previous years. Therefore, in response to such interest, Ukrainian farmers expanded the range of products produced according to organic standards (Bezus et al., 2018). Talking about Ukrainian berry market, foreign marketing experts put a lot of effort and resources to position the berries as a vital component of the nutrition of a healthy person. Focusing the consumers' attention to the fact that to consume berries is fashionable, marketers were able to increase demand to unprecedented level. According to various analytical publications production of berries in Ukraine is increasing annually by $4 \%$ (Zahrebelny et al., 2016). Although Ukraine is one of the biggest raspberries, gooseberries, currants and cranberries producer in Europe, Ukrainians do not consume such a number of produced berries as almost the entire volume of gross berries yield is exported. Zahrebelny et al. (2016) provides several reasons for that situation: - high price abroad; Ukrainian berries are popular in European countries; - conquering new markets. The researcher claims that berry farming in Ukraine is a highly profitable business, especially if you grow organic raspberries, blackberries, blueberries. Another one big berry producer in Europe is Russian Federation. According to FAO statistics, it produced 351304 tonnes of currants per 2017 year and it is absolutely the biggest number of currants produced in any Europe country. It is possible reason why berries in Russia are used in different production areas. Veliogulu (2002) claimed that berries supplied by commercial farms, being made into an extract and preserves for candy, fillers, pastry, marmalade. Moreover, berries are used for a number of health problems such as high blood pressure, heart troubles, coughs and colds, tuberculosis, shortness of breath, kidney and bladder affections, stomach pain, duodenal ulcers and bleedings either alone or mixed with honey. What is more, Russia manages berry farming in the way that there would be created the maximum value. As Veliogulu (2002) affirmed, in Russia, even black currant leaves are also used to make a tea resembling green tea in flavour. Currants are sold to local markets through pick-your-own farms, small juicers and wineries, gourmet grocers, restaurants, and other outlets. Fresh fruit, value added food products, dietary supplements, and herbal products each present marketing opportunities. Expansion beyond local and niche markets, however, requires coordinated efforts between grower and marketing organizations, as well as education of the public in the taste and nutraceutical properties of these fine berries (Hummer et al., 2002). Talking about Europe currants market, according to Veliogulu (2002), black currants dominate the European Ribes market. Rohm et al. 

Issues

(2015) agrees that black, red and white are economically significant in Russia, Poland, Germany, Scandinavia, Great Britain, New Zealand, and many eastern European countries. Cold hardiness and early ripening make Ribes viable alternatives where winters are too cold or growing seasons too short and cool for grapes or other berry or tree fruit crops (Barney, 2000), so it makes currants attractive for farmers. Although strong currants' flavor makes fresh berries rather unpalatable, juice, jams, syrups, and wines are popular products. Black currants are also used to colour yogurt and other dairy products. Red currants can also be used for juice and are often processed into jellies and syrups. The large seeds limit fresh consumption, but there are niche markets for fresh red and white currants to be used in garnishes and other culinary applications (Veliogulu, 2002). Black currant breeding or selection programs are significant in Belgium, the Czech Republic, Denmark, Finland, France, Germany, Hungary, Latvia, New Zealand, Poland, Russia, Sweden, The Netherlands, Ukraine, and the United Kingdom. Recent breeding efforts have doubled fruit size compared to fruit from wild species (Hummer et al., 2002). Talking about the challenges that currants' growers face in managing berries farms, it includes labour, marketing, diseases, and pests. However, careful site and cultivar selection reduce production problems. As Hummer et al. (2002) claimed, harvesting currants is an intensive process that accounts for $60 \%$ to $70 \%$ of the crop labour needs. To reduce labour costs, tractor driven, or self-propelled mechanical harvesters are usually used for large farms. Machine harvested currants are used only for processing. Barney (2000) added that labour requirements can be also reduced through efficient field layout and the use of hand-held shakers or over-row mechanical harvesters. What makes currants even more acceptable for berry growers, currants are nutritious and easily made into many value-added products (Barney, 2000). According to Rohm et al. (2015), pomace is beneficial to human nutrition. Therefore value can be added to the processing of soft berry fruits, when strategies and technologies are developed that make berry pomace usable as a food ingredient. Authors added that for reducing residue devaluation along the processing chain, it is necessary to increase the producer's awareness towards products that, until now, are regarded as waste, and to build systematic strategies to find new markets for value-added intermediate ingredients processed from that waste. Together with awareness that can be created in consumers, the utilization of processed berry pomace may contribute to more sustainable food utilization. As Rohm. et al. (2015) claimed, recycling methods that add value to fruit processing residues are of great interest, and it can be expected that the overall profit from fruit processing may be increased by an efficient and sustainable waste stream-management.

Results. Concluding, the biggest berry producers apply different berry farming management strategies for developing, adapted to selected kind of berries. What is common in berry growers' behaviour, they all make efforts to grow the best quality harvest and to realize it in competitive market, meeting the needs of consumers. After the analysis of the main berries producing countries in Europe, it could be highlighted some of the features, that berry growers should put attention to. Managing berry farming it is important to choose the most fertile area where land and climate are appropriate for different kind of berries; to make the best harvesting solution, whether it is manual or mechanical work; it is important to create high added value production, especially from berry production waste, that it would be not only profitable solution for producer, but also a good move for saving environment. Finding the balance between all these elements could lead berry farms to successfully development and gaining the maximum profit. Concluding analysis of the situation of berry farming in Europe countries, it has been revealed that the leading countries in Europe in berry farming are Poland, Russian Federation, Ukraine, Germany and Spain. Poland is the biggest producer of strawberries, Russian Federation generates the biggest amount of currants production, Ukraine produces significant amount of raspberry production, Germany and Spain are also specializing in strawberry production, comparing to other kind of berries. Tu sum up the amount of production by different kind of berries, there are produced the biggest amount of strawberries, raspberries and currants production in Europe. 

Issues

It was established that there are a lot of different parameters that affects successful berry farming. The main parameters are yield efficiency, added value creation and meeting the consumers' demand in order to production realization. The biggest berry producers apply different berry farming management strategies for developing, adapted to selected kind of berries. However, they all make efforts to grow the best quality harvest and to realize it in competitive market, meeting the consumers' needs. It could be highlighted that managing berry farming it is important: to choose the most fertile area where land and climate are appropriate for different kind of berries; to make the best harvesting solution, whether it is manual or mechanical work; it is also important to create high added value production, especially from berry production waste, that it would be not only profitable solution for producer, but also a good move for saving environment. Finding the balance between all these elements could lead berry farms to successfully development and gaining the maximum profit.

Conclusions. Berry farming as business is quite developed in Europe. Countries provide big amounts of harvest to European markets for direct consumption and further products in food sector. It is an important sector of agriculture and one of the potential strong bio businesses. Biggest producers are Poland, Russia, Ukraine, United Kingdom, but each country has some competitive advantage in growing berries. Development tendencies in berry farming are based on many important things related to organisational and management issues such as technological process, organic farming potential, high added value product creation, bio business directions, sustainable farming. Perspectives are positive but it should be selected priorities and ways how to develop berry farming in Europe. Berry farming in each country should analyse properly market conditions, competition and priorities of each country in production of berries. Bigger countries can compete in terms of amount, smaller ones should find competitive advantage in management and organisational issues of berry farming. For the prospects for further research in this area, a more detailed analysis of the specific country or individual kind of berry, based on the main highlighted criteria of successfully berry farm development could be carried out.

Author Contributions. Conceptualization, J. G.; methodology, J. G., D. M., A. I.; formal analysis, D. M.; investigation, J. G., D. M., A. I.; resources, J. G., D. M., A. I.; writing-original draft preparation, J. G., D. M., A. I.; writing-review and editing, J. G., D. M. A. I.; supervision, J. G.; project administration, J. G.

Funding. The paper is funded under the program of Minister of Science and Higher Education titled "Regional Initiative of Excellence" in 2019-2022, project number 018/RID/2018/19, the amount of funding 10788423,16

\section{References}

Baby, B., Antony, P., Vijayan, R. (2017), Antioxidant and anticancer properties of berries, Critical Reviews in Food Science and Nutrition 2017, 58: 1-17.

Barney, D. L. (2000), Commercial Production of Currants and Gooseberries in the Inland Northwest and Intermountain West of the United States: Opportunities and Risks, HorlTechnology, 10(3): 557-561.

Barro, J. (2014), Americans are eating a lot more berries. Here's why, available at: https://www.nytimes.com/2014/12/02/upshot/americans-are-eating-a-lot-more-berries-heres-why.html (accessed 22 May 2019).

Bezus, R., Bilotkach, I. (2018), Development of organic farmers' cooperatives: the usa, the eu, and ukraine, Baltic Journal of Economic Studies, 4,2 (2018): 24-31.

Bhat, R., Geppert, J., Funken, E. et al. (2015), Consumers Perceptions and Preference for Strawberries - A Case Study from Germany, International Journal of Fruit Science, 15 4: 405-424.

Castro, D., Teodoro, A. (2015), Anticancer properties of bioactive compounds of berry fruits - A review, British Journal of Medicine \& Medical Research, 6(8): 771-794.

Export Opportunity Surveys. (2017), The Market for Fresh Organic Strawberries in Germany and The United States, Research Paper, 1/2017. Whitewater: University of Wisconsin. 
Falco, I., Randazzo, W., Sanchez, G. et al. (2019), On the use of carrageenan matrices for the development of antiviral edible coatings of interest in berries, Food Hydrocolloids, 92: 74-85

Farruggiaa, D., Crescimannoa, M., Galatia, A. et al. (2016), The quality perception of fresh berries: an empirical survey in the German market, Agriculture and Agricultural Science Procedia 8: 566-575.

Feliziani, E., Landi, L., Romanazzi, G. (2016), Effects of field treatments with alternatives to conventional fugicides on strawberry fruit quality parameters and postharvest decay., Acta Horic, 1144: 317-324.

Food and Agriculture organization of United Nations (2019), available at: http://www.fao.org/faostat/en/\#data/QC (accessed 4 May 2019).

Guerrino, M., Giovanna, G., Bellio, A. et al. (2018). Microbiological Parameters in the Primary Production of Berries: A Pilot Study, Foods, 7. 105:1-13

Gugala, A. K., Ledwozyw-Smolen, I., Augustynowicz, J. et al. (2015), Antioxidant properties of fruits of raspberry and blackberry grown in central Europe, Open Chemistry, 13(1): 1313-1325.

Hummer, K. E., Barney, D. L. (2002), Currants, HorlTechnology, 12(3):377-387.

Invenire Market Intelligence (2008), Berries in the World, Introduction to the international markets of berries, available at: https://media.sitra.fi/2017/02/28141842/Berries20in20the20world-2.pdf (accessed 23 May 2019).

Juan, C., Oueslati, S., Mañes, J. (2016), Evaluation of Alternaria mycotoxins in strawberries: quantification and storage condition, Food Additives \& Contaminants: Part A, 33,5: 861-868.

Juranic, Z., Zizak Z. (2005), Biological activities of berries: From antioxidant capacity to anti-cancer effects, Biofactors, 23(4): 207-211.

Kowalenko, C.G. (2005), Accumulation and distribution of micronutrients in Willamette red raspberry plants. Canadian Journal of Plant Science 2005, 85: 179-191.

Kruger, E., Josuttis, M., Netsby, R. et al. (2012), Influence of growing conditions at different latitudes of Europe on strawberry growth performance, yield and quality, Journal of Berry Research, 2, 3: 143-157.

Lefevrea, I., Ziebela, J., Guignarda, C. et al. (2011), Evaluation and comparison of nutritional quality and bioactive compounds of berry fruits from Lonicera caerulea, Ribes L. species and Rubus idaeus grown in Russia, Journal of Berry Research 1(2011): 159-167.

Lozano, D., Ruiz, N., Gavilan, P. (2016), Consumptive water use and irrigation performance of strawberries, Agricultural Water Management, 169(2016): 44-51.

Macori, G., Gilardi, G., Bellio, A. et al. (2018), Microbiological Parameters in the Primary Production of Berries: A Pilot Study, Foods 2018, 7, 105: 1-12

Matyaszek, A., Szpyrka, E., Podbielska, M. et al. (2012), Pesticide residues in berries harvestedfFrom south-eastern Poland (2009-2011), Rocz Panstw Zakl Hig 2013, 64(1): 25-29.

Maunula, L., Kaupke, A., Vasickova, P. et al. (2013), Tracing enteric viruses in the European berry fruit supply chain, International Journal of Food Microbiology, 167: 177-185.

Michal, J., Sujova, A., Brezina, D. (2018), The importance of products made of certified wood materials to consumers in the Czech Republic, Forum Scientiae Oeconomia, 6, 3 (2018): 119-131.

Nile, S. H., Park, S. W. (2014), Edible berries: Bioactive components and their effect on human health, Nutrition 2014, 30: 134-144.

Perea, R. G., Garcia, I. F., Arroyo, M. M. et al. (2017), Multiplatform application for precision irrigation scheduling in strawberries, Agricultural Water Management, 183(2017): 194-201.

Rohm, H., Brennan, Ch., Turner, Ch. et al. (2015), Adding Value to Fruit Processing Waste: Innovative Ways to Incorporate Fibers from Berry Pomace in Baked and Extruded Cereal-based Foods - A SUSFOOD Project, Foods, 2015, 4: 690-697.

Statista (2015), Per capita consumption of fresh berries in the United States from 2000 to 2015. Available at: https://www.statista.com/statistics/257200/per-capita-consumption-of-fresh-berries-in-the-us/ (accessed 22 May 2019)

Sedik, P., Horska, E., Skowron-Grabowska, B. et al. (2018), Generation marketing in strategic marketing management: case study of honey market, Polish Journal of Management Studies 2018, 18(1): 326-337.

Skrovankova, S., Sumczynski, D., Mlcek, J. et al. (2015), Bioactive Compounds and Antioxidant Activity in Different Types of Berries, International Journal of Molecular Sciences 2015, 16: 24673-24706.

Tefera, T., Tysnes, K. R., Utaaker, K. S. et al. (2018). Parasite contamination of berries: Risk, occurrence, and approaches for mitigation, Food and Waterborne Parasitology, 10: 23-38.

Velioglu, Y. S., Ekici, L., Poyrazoglu, E. S. (2002), Phenolic composition of European cranberrybush (Viburnum opulus L.) berries and astringency removal of its commercial juice, International Journal of Food Science and Technology 2006, 41: 10111015.

Vittori, L. D. Mazzoni, L., Battino, M. et al. (2018), Pre-harvest factors influencing the quality of berries, Scientia Horticulturae 233: $310-322$

Willer, H., Schaak, D. (2015), Europe: Current Statistics Organic Farming and Market Development in Europe, in: The World of Organic Agriculture 2015 (pp. 181-214), Frick and Bonn.

Willer, H., Schaak, D., Lernoud, J. (2018), Organic farming and market development in Europe and the European Union, Organics international: The world of organic agriculture. Frick and Bonn: 217-250. 
J. Greblikaite, A. Ispiryan, D. Montvydaite. Development of Berry Farms in Europe: Organisational and Management Issues

Zahrebelny, D., Gavrilyuk, A., Barabas, D. et al. (2016), Optimization of pressure on agricultural land of Ukraine and maximizing the profits of the agriculture sector, Экономика сельского хозяйства. Продовольственный комплекс, 2016: 63-65.

Zbanca, A., Negritu, G., Stratan, D. (2018), Benchmarking of Investment and Their Recoverability in The Berries Sector, Scientific Papers Series Management, Economic Engineering in Agriculture and Rural Development, 18: 529-536.

Джоліта Греблікіте, Ph.D., Університет Вітовта Великого (Литва);

Аудрона Іспірян, Університет Вітовта Великого (Литва);

Деймена Монтвидайте, Університет Вітовта Великого (Литва).

Розвиток ягідних фермерських господарств в Європі: організаційні та управлінські аспекти

У статті авторами систематизовано аргументи та контраргументи у рамках наукової дискусії з питань розвитку ягідних фрермерських господарств у Європі. Головною метою дослідження є виявлення можливостей та шляхів розвитку ягідних фермерських господарств у Європі з урахуванням їх організаційних та управлінських аспектів. Об'єктом дослідження є ягідні форммерські домогосподарства країн ЄС. Для досягнення поставленої мети авторами виокремлено наступні завдання: проаналізувати особливості функціонування ягідних фермерських домогосподарств у країнах ЄС; оцінити можливості розвитку ягідних фермерських домогосподарств на міжнародному рівні (продукція із високою доданою вартістю, бізнес із високою доданою вартістю, тощо); виділити ключові аспекти подальшого розвитку ягідних фермерських домогосподарств в Європі. У рамках статmі проаналізовано ягідні домогосподарства та фермерство у Європі. Авторами розглянуто популярні види ягід у Європі, а саме: полуницю, малину, агрус, смородину, чорницю, журавлину, ожину, лохину, білу та червону шовковицю, миртові ягоди і черешню. У свою чергу, вихідні дані для дослідження сформовано на основі різних статистичних джерел щодо збору врожаю, врожайності та виробництва ягід у період 2013-2017 років. Методологію дослідження засновано на ситуаційному аналізі ягідного фермерства у Європейських країнах, основою якого є порівняльний аналіз статистичних даних у поєднанні із поглибленим аналізом наукової літератури з досліджуваної тематики. Таким чином, у статті висвітлено основні ніші потенційної конкурентоспроможності та розвитку ягідних фрермерських господарств. У результаті аналізу статистичних даних авторами визначено основні ягідні фрермерські господарства та об'єми виробниитва основних видів ягід у Європі. Результати аналізу наукової літератури з теми дослідження та прикладів ефективного управління ягідним фермерством дозволили розкрити основні організаційні та управлінські особливості для формування дієвого механізму розвитку ягідного фермерства. Авторами зазначено, що отримані результати дослідження можуть бути корисними для розвитку успішного ягідного фермерства у Європейських краӥнах.

Ключові слова: ягідні фермерські господарства, урожайність ягід, ягідне фермерство, виробництво ягід, менеджмент у сільському господарстві.

Manuscript received: 19.02.2019.

(C) The author(s) 2019. This article is published with open access at Sumy State University. 